\title{
Logistic Architecture Based on Models
}

\author{
Tania Regina Brasileiro A. Teixeira, Márcio Lopes Pimenta \\ Federal University of Uberlandia, Uberlandia, Brazil \\ Email: pimenta.mp@gmail.com, taniateixeirabr@yahoo.com.br
}

Received 22 October 2014; revised 20 November 2014; accepted 10 December 2014

Copyright (C) 2014 by authors and Scientific Research Publishing Inc.

This work is licensed under the Creative Commons Attribution International License (CC BY). http://creativecommons.org/licenses/by/4.0/

(c) (i) Open Access

\begin{abstract}
The article identifies the essential dimensions in relation to outsourced logistic management, through a study of the outsourcing process of a large Brazilian wholesaler distributor's logistic activities. The author has developed a management tool able to guide and direct the outsourcing operators of integrated logistic services so as to allow them to organize their management system. The author proposes a logistic architecture based on models which will facilitate the managerial work and transform the logistic system into a strategic skill, thus leveraging its ability to compete in the market. This idea is focused on the client, and is capable of integrating and managing all the interface elements of the logistic system, connecting and joining all of them in order to perform more organized and structured logistic activities. Therefore, the logistic architecture based on models represents the nature and structure of a logistic system as well as determines the way for it to operate.
\end{abstract}

\section{Keywords}

Logistic Architecture, Management Models, Logistic Operators

\section{Introduction}

A selected bibliographical research and a study of the outsourcing process of the logistic activities inside a large Brazilian wholesaler distributor have brought, as a main consequence, the development of an architecture for logistic organization inside the company based on models. Actually, this architecture is an interesting tool, which aims to guide companies outsourcing logistic services in designing their structure, planning and strategic management of their logistic systems.

The main reason for designing such architecture was the study of this case done by the author and the new awareness that it has raised. The companies included in the study were going through a transition period, in a complex scenario, which involved a decision by the wholesaler to outsource or not its logistic activities with a logistic operator. There was a series of concerns related to this decision, specially the potential impact that it would have on the internal elements of both organizations. 
On one side, the wholesaler distributor would disassemble its logistic managerial and operational structure; on the other hand, the logistic operator would have to work hard to realign the structure, strategy and culture of the logistic processes - both managerial and operational-and also the roles of the different areas and individuals, through a logistic process which would answer the following questions: Where and how to begin? What should be done to structure the key areas with minimum costs? Was there a way to set apart the strategy of the logistic operator to restructure the company's system?

With these questions in mind, the author tried to find a way to structure the key areas of the logistic operator. Thus, there came the idea of designing a logistic architecture based on models, which, in its essence, could represent the nature and structure of a logistic system, as well as establish a way for them to operate.

\section{Logistic Architecture Based on Models}

The logistic architecture designed by the author consists of a group of systematically structured models, with defined objectives which characterize the logistic service life cycle. Under this perspective, the following premises were considered when designing the architecture:

The approach to design the architecture is systemic, meaning that the various parts are closely related and that any action relating to one component must take into consideration all the others.

The architecture must be built based on a competitive strategy developed by the logistic operator.

The logistic architecture encompasses tow large areas: processing the business inteligence and supporting the logistic needs of the company's operations.

It's possible for the models to become a reality since they were thought of within the humanistic perspective, once man is the center of the whole structure. The architecture exists, therefore, to serve the needs and expectations of logistic services. Besides, man is the one who operates the architecture, and he's the origin of all the solutions to problems which come to be processed, not only that, but also all the benefits from this kind of organization turn to him.

The logistic service life cycle originates in the need of the client, who demands an efficient structure from the company. The company must turn the need into a desirable solution, and therefore needs an intelligent model to process logistic responses capable of answering the needs and demands. The cycle ends when the satisfied customer receives the service as ordered and in order to achieve such result the company has to have an information structure capable of helping it measure, point out and manage the level of services rendered to the client. Only then will the company be able to to know its performance in terms of responding to orders and refeeding the system so as to improve its processes continuously. The sequence is well explained in Picture 1.

Therefore, the logistic architecture based on modules is developed as a tool to be used in the strategic management of logistic operators, based on theory and the case study, and with these suppositions guiding the author's reasoning. In this sense, the architecture can be used by operators as an ideal to be reached, or as a reference for all of them when looking for management practices for their logistic systems.

The idea is that the architecture, besides incorporating the previous suppositions, be based on two other aspects. It's believed that in order for a company to achieve good results in a long term, and consequently increase its businesses and market share and also provide its shareholders with good revenue, it must have a well established business strategy and an efficient operation.

Based on studies by several authors [1]-[3], we can consider an strategy to be a group of formulations, rules and plans which guide the behavior of an organization to reach a particular goal; a sight reflecting the image of what the people in a company expects it to become; a mission, translated in the need of the client, the value premise offered and the means to generate this value, the action pattern developed by the organization through a long period of time and the organization's positioning in the market. On the other hand, to indicate a concept of operational efficiency, we use [4], to whom the function of production is to gather the resources destined to the processing of a company's goods and services, it's efficient to use effectively its resources and provide goods and services in a way to satisfy its customers.

These two elements are essential, meaning that there is no use for a company to try to improve its logistic operation system, by using a group of techniques widely known and divulged instead of a well elaborated strategy. The same is true for the opposite idea, to have a company use a lot of time and energy in the elaboration of a strategy and not give attention to the way it performs various activities along the execution of services cycle.

In this way, we understand that the capacity of the operator to compete is strongly influenced by these two elements. The logistic architecture and the models must be developed with this reference in mind. So, the 


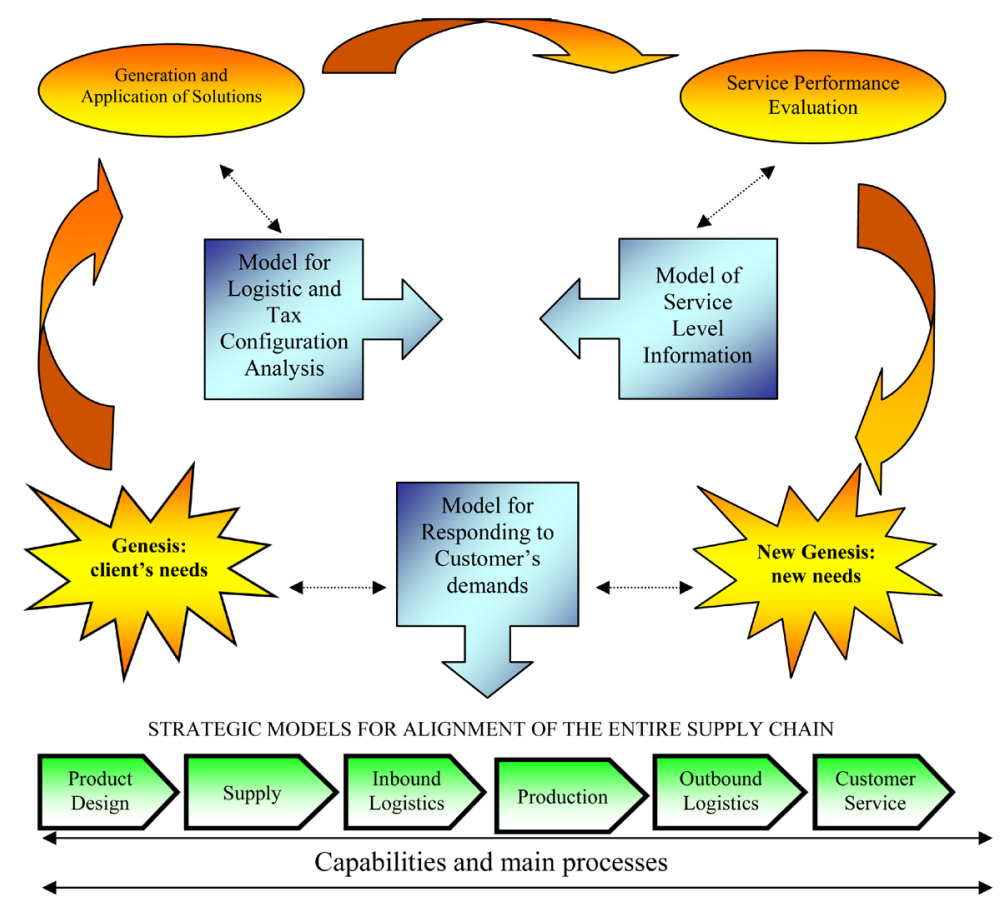

Picture 1. Logistic services life cycle. Source: Created by the author. In this chart we can show the relation between the phases of the logistic services life cycle and the strategic models idealized in the study.

strategy is developed by taking into consideration the established view, mission and strategies, and is supported by a logistic operationalization model which contemplates physical and technological structures capable of making this type of organization efficient in its operation.

In this context, Picture 2 presents the logistic architecture based on models proposed in the study, in details as follows:

The author defends the idea that the logistic operator must set up the essential processes of the logistic system in two large areas:

The first area - the Intelligence-is related to the continuous processes which elaborate the whole business intelligence so as to respond as quick as possible to internal and external clients' needs. In order to have that, according to the premise, responding to the logistic services life cycle, it's essential to elaborate a way to: respond to client's demands, the processing of intelligent viable answers to different questions posed by internal and external clients; and the information, which can be used to measure, point out and manage the service level rendered by the company to its clients.

The second-the infrastructure area-refers to the continuous processes serving as the foundation of the architecture, which are supported by the infrastructure supporting the company's logistic operations and refer to the technological, transportation and physical structure. The author understands that elaborating the planning and strategic design of these areas is essential to ensure competitiviness capable of connecting production to consumption

This concern is relevant because these are the structures which transmit value to the client and allows the right goods to be delivered, at the right time, right amount, right place, in good conditions and at a minimum cost, which also make the accurate information report of the logistic operation and tracking of the order possible, so as to efficiently respond to client's demands and requirements.

Therefore, in order to structure the Intelligence area, the researcher points out the need for companies to develop a model to respond to client's needs, a logistic intelligence processing system which must include the supply, production and distribution management model, besides establishing an information model which can measure the logistic service level. The author also shows the need to organize the infrastructure area companies have so as to establish a logistic operationalization model. We can present as follows, each component of the logistic architecture and how they interact with each other to have a harmonic and efficient whole. 


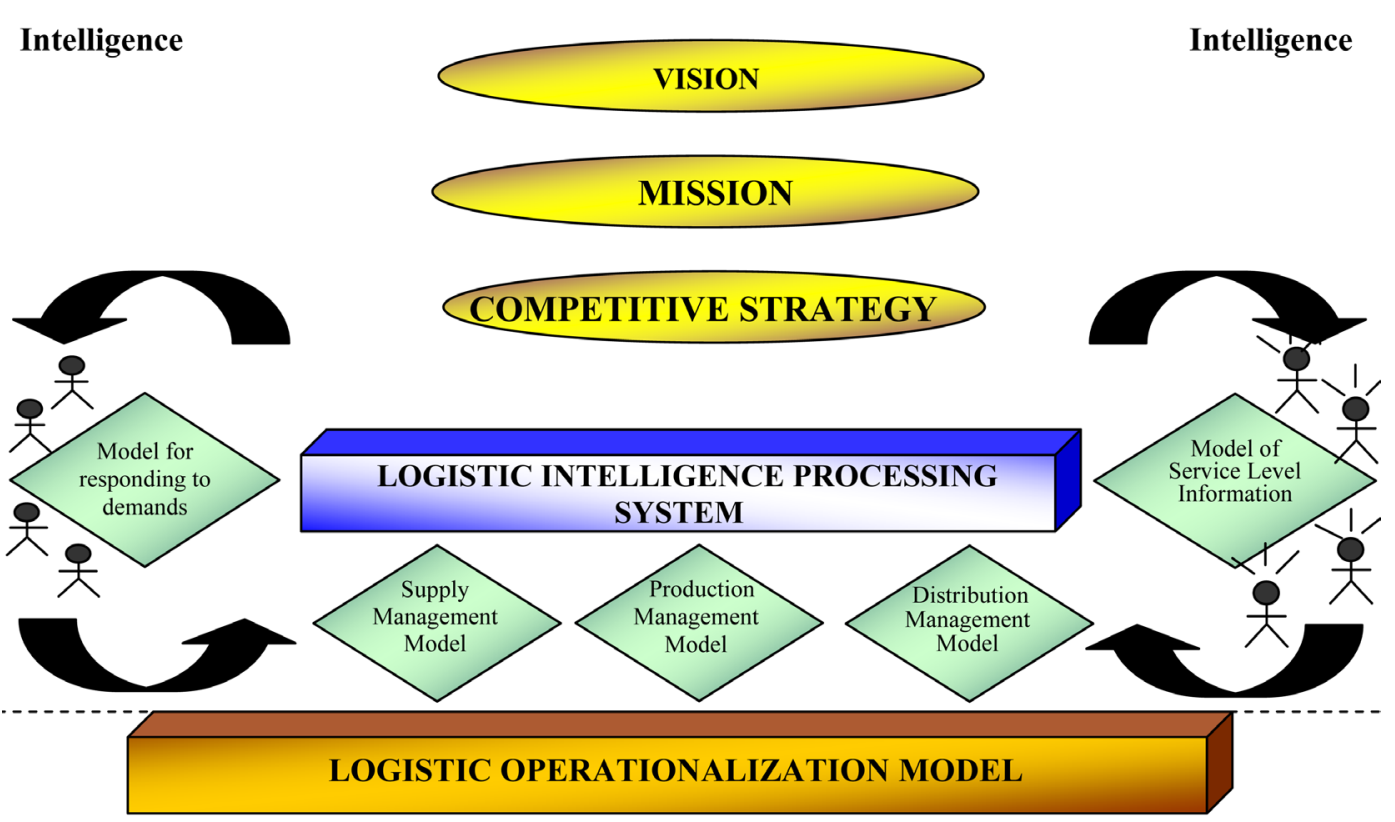

Infrastructure

Infrastructure

Picture 2. Logistic architecture based on models. Source: Created by the author.

The Model for Responding to Customer's Demands for Logistic Services—should deal with the important issue of customer service. When considering the gateway of the entire logistic architecture, the author realized, through bibliographic research and case study, just how this area is still underdeveloped, both academically and business wise. Part of the literature studied shows a discentralized initiative by some authors in relation to the topic. So, the author gathered some of these studies such as the ones by [5]-[8] which deal with the important issue of customer service called, respectively: Serviço ao Cliente (Customer service); Rentabilidade de Clientes e Nível de Serviço (Client profitability and service level); Segmentação de mercado para diferenciação dos serviços logísticos (Market segmentation to set apart logistic services); and Custos logísticos: uma visão gerencial (Logistic costs: a management view).

These studies were the foundation used by the author to understand the importance of taking client demand response architecture into consideration. Thus, the idea is that the logistic operator should be able to establish a group of principles and logical rules which stimulate the organization to act in a different manner, aiming to respond to different needs of various clients, in such a way not to increase costs dramatically. Therefore, the idea is to develop a model which can be used as reference for the company to establish a good customized logistic service structure, with an efficient cost and which responds to client's demands at the same time, help the organization distribute resources and logistic efforts along the process more effectively.

The Logistic Intelligence Processing System-it's the core of this whole structure and a key area for the development of the logistic operator's business. In this system, the entire supply chain management has to be processed, which requires the organization to use the following models:

Supply Management Model-should answer to the purchase management, stock, storage and transportation. Relevant Questions: Is the stock management appropriate for service demand? What is the best way to relate to suppliers? How can we establish strategic partnerships and alliances along the supply chain?

Production Management Model-should answer questions related to scheduling (program) and production, flexibility, productivity and synchronism management, etc. Relevant Questions: What is the best technology? Which are the right methodologies to be implemented? How can we integrate the distribution channels?

Distribution Management Model — should answer questions in relation to forecasting demand, distribution, channel and network, type of transport, more appropriate premises, among other topics. Relevant Questions: What is the best distribution system? Is there a methodology to better establish a tax and logistic solution? What is the best route in terms of taxes? Are these opportunities to optimize the transport system? What is the best 
distribution network? According to Picture 1, the author approaches the spefic need for the distribution management model to definy and implement an analysis model of the logistic and tax configurations so as to structure the decision making process thus enabling a better solution to be provided to the customer.

All of these issues and questions, to be dealt with on a daily basis in companies, should have well established models and answers which would be able to explain or forecast, based on theory, the structure and the behavior of the areas which constitute the logistic operator's intelligence processing system.

The Information Model of the Logistic Service Level—from the moment when customized service packages can be defined and offered to the client to measure and analyze the logistic performance is also an important variable when referring to service level. Performance techniques and measures adopted for current logistic reality are critical, because the effective cost control of operations requires appropriate information about the logistic performance.

The author concluded, during the case study and experience as a consultant, that most companies need more structured measures and data banks in order to manage their logistics, because the systems, many times, offer disconnected and unnecessary information in relation to the decision making process. She has also realized that there isn't a consensus about what is being measured from collaborators.

Therefore, these measures should be well defined and established so as to guarantee that the logistic service is adjusted to the desired goals. And also, to control the logistic activities processing, to verify an operation accuracy and compare the performance the company wants to attain. The logistic operator must develop an information model about the logistic service level.

The idea is for the operator to be able to formulate a group of principle about the structure which must be used to organize a series of information that are part of a specific and defined measuring system, in such a way that it's possible to manage the level of the service rendered by the logistic operator to its clients.

The Logistic Operationalization Model—it's responsible for establishing a group of principles concerning the planning and strategic design of technological, transport, and physical structure, which support a company's logistic operations. These operations have a vital role to be played in the supply chain, because they connect the suppliers', manufactures' and distributors' units to the client and even to the client's clients. As a consequence, these well established structures can significantly alter the operational expenses, the fixed assets and level of client satisfaction.

Despite this importance, such structures, a lot of times, are neglected by the management. So, the author mentions the need for the logistic operator to look for operational efficiency, establishing a logistic operationalization model concerned with: integration of these relevant structures and activities, achieve strategic efficiency and obtain competitive advantages by offering services with a differential and reduced costs of equipment, vehicles, premises and information systems.

The author also points out that client satisfaction and the recipe are directly related to the speed, reliability, and flexibility these structures allow.

So, all effort made to design the logistic operationalization model proposed in the architecture will allow the logistic operator to significantly leverage its results. Thus, this type of organization should adopt a more strategic view in relation to these structures, recognizing the abilities these structures have to improve business initiatives, allow new strategies to be adopted for the supply chain and add competitive advantage to the company.

\section{Interaction among Models}

After describing the models which constitute the logistic architecture, it’s important to briefly mention how they interact. The customer service structure receives the needs for service from clients, in which services and clients are separated into different segments and classified, respectively, in a customized manner; this characterizes the information input which activate the logistic intelligence processing system, consisting of supply, production, and distribution management models to be answered, with intelligent and viable solutions to various required needs, which reach the clients/consumers through the logistic operationalization model. After that, the service must be evaluated according to the information model created to measure and manage the level of the logistic service rendered.

Finally, the five proposed models may contribute as important tools to manage and evaluate the ability to generate value with supply chain management. It can also serve as a criteria to decide about outsourcing of activities, for example: a company may be good in the service level and demand management and bad in the 
distribution management. This company can verify which parts of the model, considered as weak, are essential to add value to the customer and give focus to improve them. On the other hand, this company may perceive that this activity can be outsourced without a risk of value loss to the customer.

\section{Conclusions}

According to [9], the usage of logistic operators is, without a doubt, one of the most important trends in modern business logistics, both locally and globally. In Brazil, such phenomenon is also a reality [10]. The Brazilian market of logistic operators has been going through, over the last five years, a continuous growth, and has showed continuous changes: the appearance of new companies, mergers and acquisitions, and even international operators. Therefore, the logistic operator needs to be better prepared to face the increasing competition.

This paper contributes to supply chain literature with the development of an integrated view of logistics infrastructure and logistics intelligence, in a way that the balance of these two managerial efforts can generate better results in the processes of customer value transfer. In a practical context, wholesaler companies seems to focus more on the infrastructure side than on the logistics intelligence or on a balance of these.

Another conclusion is related to the five different proposed models. Three of them are often mentioned in the literature (Supply Management Model, Production Management Model, Distribution Management Model). In addition, the authors conclude that companies should adopt the Model for Responding to Demands and the Model of Service Level Information in order to increase their abilities to balance logistics infrastructure and logistics intelligence issues. This initiative may contribute to improve the demand answering management and the service level.

In this context, the logistic architecture developed has conjugated models with clear pre-determined goals to be used in the execution of a certain activity and/or administrative actions. This theory focuses on the client and aims to integrate and manage all the interface elements of the logistic system, by connecting and uniting strength for the organized and structured exercise of all logistic activities. Considering a practical aspect, this paper provide explanation of supply chain processes in wholesalers distributors companies, in a way to detail some specific problems and suggestions to improve its management.

Therefore, each model cited here, when well structured, can leverage the client satisfaction level, as long as the client is well served in his/her needs, satisfied with the solution provided, rendered with the right service and product at the right time and under the right conditions, with reasonable costs, and receives information concerning the logistic operations, content, times and positions of a certain order to support his decision making process.

\section{References}

[1] Ansoff, H.I. (1990) A nova estratégia empresarial. Tradução de Antônio Zorato Sanvicente, Atlas, São Paulo, 257 p.

[2] Mintzberg, H. (1996) Five PS for Strategy. In: Mintzberg, H. and Quinn, J.B., Eds., The Strategy Process-Concepts, Contexts, Base, 3rd Edition, Prentice Hall, Upper Saddle River, 10-17.

[3] Albrecht, K. (1995) Programando o futuro: O trem da linha norte. Tradução de Maria Lúcia G. L. Rosa, Revisão técnica José Ernesto Lima Gonçalves, Makron Books, São Paulo.

[4] Slack, N., Chambers, C., Harrison, A. and Johnston, R. (1995) Operations Management, Warwick Business School. Pitman Publishing, London.

[5] Christopher, M. (1994) Creating Effective Policies for Customer Service. Logistics and Supply Chain Management, Financial Times, Irwin Professional Publishing, Burr Ridge.

[6] Figueiredo, K.F. (2000) Rentabilidade de clientes e nível de serviço. In: Fleury, F., Wanke, P. and Figueiredo, K.F. Orgs., Logística empresarial: A perspectiva brasileira, Atlas, São Paulo.

[7] Hijjar, M.F. (2000) Segmentação de mercado para diferenciação dos Serviços logísticos. In: Fleury, F., Wanke, P. and Figueiredo, K.F., Orgs., Logística empresarial: A perspectiva brasileira, Atlas, São Paulo.

[8] Lima, M.P. (2000) Custos logísticos: Uma visão gerencial. In: Fleury, F., Wanke, P., Figueiredo, K.F., Orgs., Logística empresarial: A perspectiva brasileira, Atlas, São Paulo.

[9] Bowersox, D.J. and Closs, D.J. (2001) Logística empresarial: O processo de integração da cadeia de suprimento. Atlas, São Paulo.

[10] Fleury, P.F. (2002) Vantagens competitivas e estratégicas no uso de operadores logísticos. Centro de Estudos em Logística-Coppead-UFRJ. http://www.coppead.ufrj.br/pesquisa/cel/new/fs.public.htm 
Scientific Research Publishing (SCIRP) is one of the largest Open Access journal publishers. It is currently publishing more than 200 open access, online, peer-reviewed journals covering a wide range of academic disciplines. SCIRP serves the worldwide academic communities and contributes to the progress and application of science with its publication.

Other selected journals from SCIRP are listed as below. Submit your manuscript to us via either submit@scirp.org or Online Submission Portal.
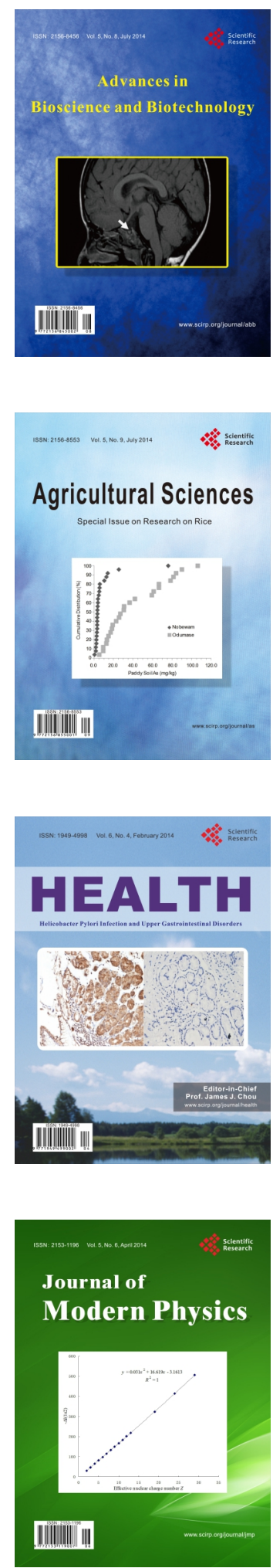
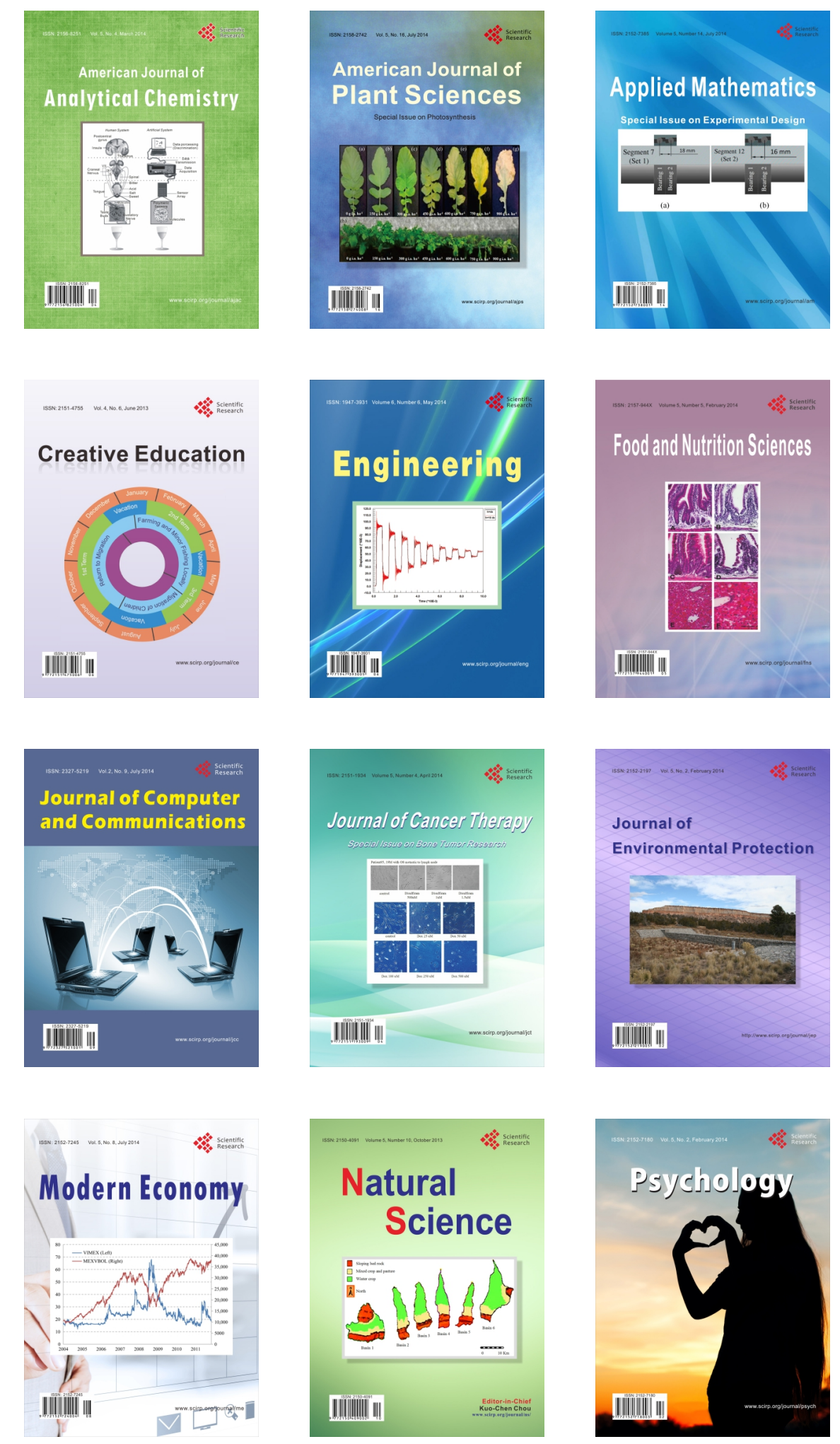